\title{
УДК 635.64: $(631.527+631.5)$
}

КРАВЧЕНКО В. А., доктор с.-г. наук, професор, академік НААН

Національна академія аграрних наук України

e-mail: cropnaan@yandex.ru

\section{МЕТОДИЧНІ ПІДХОДИ ДО СЕЛЕКЦЙНОГО ПРОЦЕСУ В ОВОЧІВНИЦТВІ}

Висвітлено методичні підходи до створення нових сортів $і$ гібридів помідора різних напрямів використання плодів. Використовуючи розроблені методики отримано ряд сортів $i$ гібридів, широко розповсюджених $y$ виробництві - Іскорка, Лагідний, Флора, Іришка, Святослав $F_{1}, K Д С-5 F_{1}$, Богун $F_{1}$.

Ключові слова: селекиійний процес, помідор, сорти та гібриди.

Bcmyn. Сучасне овочівництво вимагає гібридів $\mathrm{F}_{1}$, за основними культурами [1]. Відомо, що в гібридах можна досягти гетерозис за ознаками продуктивності, скоростиглості та поєднати в них якість, стійкість проти стресів та хвороб $[2,3]$. Селекційний процес будується за вимогами напрямків використання овочевої продукції, тобто здійснюється пошук та оцінка ознак, необхідних для задоволення певних потреб [4]. Наприклад, гібриди $\mathrm{F}_{1}$ помідора для механізованого збирання повинні мати комплекс специфічних ознак: дружність достигання, фізико-механічні властивості плодів, високу їх товарність та якість. Для промислової переробки необхідний дещо інший комплекс ознак; довготривалого збирання - зовсім інший. Вимоги до створення гібридів $\mathrm{F}_{1}$ стійких проти стресів і хвороб, різняться від названих і селекційний процес здійснюється за іншими підходами [5]. Кожний селекціонер відзначає власний підхід до методів селекції й успіх приходить до тих, хто їх вірно визначив і застосував. 
Виходячи iз вищенаведеного, метою наших досліджень було відслідкувати методики селекційних процесів з овочевими рослинами і надати рекомендації за успішним їх виконанням.

Матеріали та методика досліджень. Автор статті понад 45 років займався селекцією різних овочевих рослин, отримав біля ста авторських свідоцтв, патентів на створення вихідного матеріалу, сортів та гібридів. У своїй селекційній роботі використовував ряд існуючих методик [5] та підходів: мутагенез, поліплоїдію, внутрішньовидову та міжвидову гібридизацію, різні типи схрещувань та шляхів створення генетичного різноманіття гібридних популяцій.

При селекції на імунітет застосовувалися специфічні методики [6, 7]. Автором знайдено власні підходи при проведенні доборів на різні господарськоцінні ознаки [8, 9]. У різні роки, при різних селекційних напрямках нами застосовувалися відомі статистичні методики. Довготривала селекційна робота здійснювалася в різних кліматичних умовах Київської, Харківської, Херсонської областей, починаючи з 1971 року.

Результати досліджень. Багаторічні селекційні дослідження $з$ овочевими культурами показали, що успіх у селекції починається зі створення цільового селекційного матеріалу. Створювати його необхідно під модель майбутнього сорту, гібриду, тобто максимально наситити селекційну лінію цінними ознаками, які будуть мати майбутні сорти чи гібриди $\mathrm{F}_{1}$. Основою для створення спеціальних популяцій можуть бути мутантні форми, поліпоїди, сорти, гібриди, напівдикі та дикі форми. Схрещуючи їх з культурними сортами, лініями, ми створюємо фон для доборів необхідних вихідних генотипів. Чим більш генетично різноманітну гібридну популяцію ми створимо, тим кращим буде фон для добору цінних ознак.

В основу доборів ставляться ознаки, притаманні майбутньому сорту, гібриду. Створення скоростиглих генотипів вимагає направляти добори на ознаки скоростиглості, а створення стійких генотипів - добори рослин з генами стійкості. I таким чином по напрямах іншого використання, наприклад, для 
механізованого збирання, консервної переробки, вживання у свіжому вигляді, соління, зберігання. Кожен із названих напрямів вимагає наявності комплексу специфічних ознак. Ознаки необхідно відшукати й об'єднати в одному генотипі.

За допомогою доборів та оцінки за нащадками добирається комплекс ознак, що успадковуються. Створений необхідний вихідний матеріал схрещується для оцінок його комбінаційної та рекомбінаційної здатності 3 тестерами. Добори направляємо на створення сортів, а лінії 3 високою комбінаційною здатністю - гібридів першого покоління.

Найбільше генетичне різноманіття гібридних популяцій помідора нами отримано при віддалених схрещуваннях. Значна частина відібраних генотипів відзначалися скоростиглістю, показниками якості плодій, стійкістю проти хвороб. 3 використанням створеного генетичного різноманіття отримано сорти Іришка, Мить $з$ польової стійкістю проти фітофторозу.

Схрещуванням поміж собою вихідних форм 3 рядом рецесивних мутантних генів отримано гетерозисні гібриди помідора, що поєднували штамбовий кущ 3 детермінантним ростом 3 генами скоростиглості, сливкоподібним без плями біля плодоніжки плодом, безколінчату плодоніжку, просте суцвіття 3 одним, двома, трьома плодами. Використання мутантних генів призвело до отримання нових сортів Золотий потік, Оберіг, Дама, Художник, Консервний Київський, Аміко та інших.

Залучення в схрещування партенокарпічних вихідних форм привело до створення нового сорту помідора Еол - скоростиглого, холодостійкого, перспективного для плівкових теплиць.

За участю в схрещуваннях тетраплоїдів отримано значне генетичне різноманіття: диплоїдів, триплоїдів, тетраплоїдів 3 комплексом господарськоцінних ознак. 3 такого різноманіття створено скоростиглі сорти помідорів - Темп 35, Світанок, Іскорка.

Складні схрещування також сприяли розширенню генетичного різноманіття вихідних популяцій. Оптимальна кількість компонентів у 
схрещуваннях - шість вихідних форм. При складних схрещуваннях добори за рецесивними ознаками можна вже починати в першому гібридному поколінні. Застосування складних схрещувань сприяло отриманню скоростиглих, холодостійких вихідних форм з цінними рецесивними ознаками, таким чином створено сорти Зорень, Флора, Боян.

Схрещування поміж собою кращих гібридів українського та іноземного походження привело до створення таких відомих сортів як Лагідний, Ленгоранж, гібридів $\mathrm{F}_{1}$ Козачок і Святослав.

У процесі доборів нами розроблено ряд методичних підходів до оцінок генотипу за фенотипом: за рахунок індивідуальної оцінки кожного фенотипу, комплексного поєднання в одному генотипі ряду бажаних ознак, перевіркою успадковування їх у потомства. В процесі доборів визначалися середні ознаки в популяції, середні ознаки індивідуальних доборів, здійснювалася оцінка ступеню відмінності ознак індивідуального добору за системою +2-3G. Такими способами створювався цільовий вихідний матеріал для успішного проведення селекційного процесу, було розроблено схему селекційного процесу за напрямами використання плодів і чіткою моделлю майбутнього сорту, гібриду. Цілеспрямований вихідний матеріал, конкретна гібридна популяція для доборів, детальна індивідуальна оцінка кожної окремо і рівня поєднання ознак в одному генотипі.

У процесі доборів здійснювали оцінку на провокаційних фонах: холодостійкості, тіньовитривалості, стійкості проти розтріскування, стійкості проти фітофторозу і ВТМ. Оцінювали на приладах НДІОГ фізико-механічні властивості плодів, індивідуально в польових умовах і в лабораторних біохімічні показники плодів. Збирання плодів здійснювали одноразово, вручну, шляхом струшування і детальним аналізом кожного плода і КТМ-2 комбайном для збирання плодів на дрібних ділянках.

Розроблені підходи давали змогу створювати повноцінний вихідний, селекційний матеріал, високоякісні сорти і гібриди. При цьому важливим є кількість рослин, що вивчаються, i кількість новостворених гібридних 
комбінацій, і кількість взятих доборів з однієї популяції. Згідно існуючих теорій, як правило, в розсаднику $\mathrm{F}_{1}-10$ рослин для розпочинання доборів достатньо. В розсаднику $\mathrm{F}_{2}$ кількість рослин однієї комбінації повинна бути 300-500 шт. Чим більше доборів проводиться на фоні однієї гібридної популяції, тим більша можливість знайти унікальну рекомбінацію чи трансгресію.

У третьому поколінні бажано мати 50-100 рослин кожного добору, тому що розщеплення за ознаками продовжується. В цих поколіннях $\left(\mathrm{F}_{2}, \mathrm{~F}_{3}\right)$ добори здійснюють за рядом ознак, бажано, маркерних, рецесивних. Добираючи за комплексом ознак, можна визначитися з напрямками добрів для майбутнього сорту. Наприклад, добір низьких детермінантних зразків напряму сприятиме короткостебельності, скоростиглих рослин - скоростиглості потомків. Добір за дрібними, сливоподібними плодами не приведе до появи крупних плодів і т.д.

У процесі онтогенезу оцінку намічених для доборів рослин, здійснюють кілька разів, вибраковуючи всохлі, хворі, з плодами, що тріскаються, м’якими на дотик, перестиглі, не смачні, без аромату. При кінцевій оцінці фенотипу, що підійшов під заплановану модель, оцінюють чистоту судин рослин, бракуючи ті в яких судини побуріли, звільняючись, таким чином, від внутрішньої інфекції. Кінцеву оцінку можна здійснювати за розміром кореневої системи та використовуючи провокаційні фони.

$\mathrm{y} \mathrm{F}_{3}, \mathrm{~F}_{4}$ розпочинають оцінку ознак продуктивності та якості плодів. При оцінках на стійкість, здійснюють індивідуальне зараження кожної рослини гібридної популяції $\mathrm{F}_{2}, \mathrm{~F}_{3}$. На насіння добирають лише рослини, що поєднали бажані господарські ознаки зі стійкістю проти збудника хвороби. Звичайно, бажано оцінювати індивідуально і смакові якості за допомогою польового рефрактометра та дегустаційно.

Таким чином ми отримуємо високоякісний оригінальний матеріал, як основу нового сорту. В подальшому необхідне широке екологічне і виробниче сортовипробування. В системі овочівництва для цього $є$ всі можливості дослідні установи розміщено у всіх типових для овочівництва регіонах: АР 
Крим, Херсонська, Харківська, Дніпропетровська, Донецька, Київська, Чернігівська область. Співвиконавці наукових тематик: Черкаській, Миколаївській, Сумській, Львівській, Закарпатській областях. На думку визначного овочівника-теоретика О. О. Жученка [1], випробування в багатьох еконішах дає більш точну оцінку нового сорту, ніж випробування за кілька років.

Висновки. Таким чином, успіх у створенні нових сортів і гібридів $\mathrm{F}_{1}$ помідора забезпечують: цілеспрямований добір вихідного матеріалу, створення гібридних популяцій для доборів, добори кращих генотипів за маркерними ознаками, екологічне сортовипробування та оцінки на провокаційних фонах.

\section{Список використаних літературних джерел}

1. Жученко А. А. Генетика томатов / А. А. Жученко. - Кишинев, 1973. $662 \mathrm{c}$.

2. Пивоваров В. Ф. Селекция и семеневодство овощных культур : у 2 т. / В. Ф. Пивоваров. - М., 1999. - Т. 1. - 289 с.

3. Кравченко В. А. Помідор: селекція, насінництво, технології / В. А. Кравченко, О. В. Приліпко. - К. : Аграрна наука, 2007. - 405 с.

4. Кравченко В. А. / Методика і техніка селекційної роботи з томатом / В. А. Кравченко, О. В. Приліпко. - К. : Аграрна наука, 2001. - 82 с.

5. Селекція овочевих рослин: теорія і практика / В. А. Кравченко, 3. Д. Сич, С. І. Корнієнко [та ін.] ; за ред. В. А. Кравченка, 3. Д. Сича. - Вінниця : Нілан-ЛТД, 2013. - 362 с.

6. Диагностика устойчивости растений к стрессовым воздействиям : метод. руководство / под ред. Г. В.Удовенко. - Л. : ВИР, 1988. - 226 с.

7. Кравченко В.А. Генетика зрушення щодо стійкості до абіотичних факторів середовища у помідора / В. А. Кравченко // Цитологія і генетика. 1995. - Т. 28, № 4. - С. 31-33. 
8. Кравченко В.А. Отборы по признакам продуктивности в ранних гибридных поколений томатов / В. А. Кравченко // Селекция и семеноводство. К. : Урожай, 1987. - Вып. 47. - С. 34-37.

9. Сучасні методи селекції овочевих і баштанних культур / за ред. Т. К. Горової, І. І. Яковенка. - Харків, 2001. - 641 с.

\section{Аннотация}

Кравченко В. А.

\section{Методические подходы к селекционному процессу в овощеводстве}

Освещуены методические подходы к созданию новых сортов и гибридов томата различных направлений использования плодов. Используя разработанные методики, получено ряд сортов и гибридов, иироко используемых в производстве - Искорка, Лагидный, Флора, Иришка, Святослав $F_{1}$, КДС-5 $F_{1}$, Богун $F_{1}$.

Ключевые слова: селекционный процесс, помидор, сорта та гибриды.

\section{Annotation}

Kravchenko V.A.

Methodical approaches to the breeding process in vegetable growing

The article highlights methodological approaches to the development of new varieties and hybrids of tomato for different uses. Having used the developed techniques we obtained a number of varieties and hybrids, widespread in production, such as Iskorka, Lahidnyi, Flora, Iryshka, Sviatoslav $F_{1}, K D S-5 F_{1}$, Bohun $F_{1}$.

Keywords: breeding process; tomato; varieties and hybrids.

Надійила 28.05.2014 